\title{
De la mirada cenital a la mirada impura. La ciudad como experiencia estética ${ }^{1}$
}

\author{
Maria Gisela Escobar Domínguez \\ Universitat Autònoma de Barcelona \\ mariagisela2000@yahoo.es
}

Nuestros contornos son imágenes cuya materia no está hecha solo de lenguaje, sino de visualidad, cenestesia, afectividad. Esta materia y su encarnación hecha experiencia resultan intrascendentes en un mundo definido por los límites del verbo, del objeto y sus dispositivos de representación que hacen del sujeto, -tal y como nos señala Walter Benjamin (2005)-, un mero narrador de experiencias. Este trabajo se aproxima a una Estética Social, entendiendo la estética como algo que emerge de nuestra visión del mundo (Gadamer, 2006) y aparece como interpretación en el momento de la experiencia.

La propuesta que aquí se desarrolla es una aproximación a las ciudades a partir de tres miradas sobre la ciudad. Se presentan tres escenarios que son el lugar y la contingencia de imágenes y estéticas en un devenir corporeizado, social y político, vinculados a espacios de poder y ejercicio gubernamental y también a acciones que desde lo cotidiano proponen la subversión a estas lógicas. Cada una de estas miradas presenta al sujeto como actor de la ciudad en un particular nivel de implicación. Los escenarios son los siguientes:

a.) Escenario 1: Desde la torre: La mirada cenital.

b.) Escenario 2: En las calles: La mirada en el andar

c.) Escenario 3: La ciudad es una forma: La mirada impura

\section{ESCENARIO 1: DESDE LA TORRE: LA MIRADA CENITAL}

En la década de los 80, Michel de Certeau (2000) nos habla de un observador situado en lo alto del World Trade Center de Nueva York cuyo cuerpo no está "atado" a las calles de la ciudad, porque se

${ }^{1}$ Con el apoyo del Programa Alban, Programa de becas de alto nivel de la Unión Europea para América Latina, beca No: E04D031991VE 
alza sobre ella como una metáfora de poder y dominio sobre el territorio que contempla. Su mirada se alza omnividente sobre Manhattan.

La mirada cenital no es una mirada actuante en el espacio que intenta dominar sino que se circunscribe a un ámbito simbólico. En esta mirada, figura la racionalidad cartesiana moderna, que rige una razón ordenadora y un proyecto previo que se revela en un orden social y gubernamental. Así, la figuración se presenta no solo como contemplación, sino como simulacro teórico de la posibilidad de abarcar y dominar un vasto territorio urbano, cuyos horizontes parecieran ser lejanos y borrosos.

Esta mirada es análoga a una forma de representación del conocimiento: el saber como mirada objetiva y la concepción de ciencia como control y dominio del objeto. Esta mirada también refiere a una ciencia cuya pretensión de objetividad se caracteriza por desconfiar de realidades singulares porque prefiere confiar en los instrumentos y dispositivos ad-hoc que ha diseñado para mirar y representar. La mirada cenital es análoga a la simulación de un mundo a escala cuyas características son icónicas al "mundo real", como la maqueta del arquitecto que nos presenta un modelo total y real.

Pero también la mirada cenital sobre la ciudad figura los espacios de poder y control, los cuales son referidos por Foucault, en sus trabajos sobre geografía y gubernamentalidad (1976; 1978), espacios que a su vez se vinculan a determinados ejercicios del conocimiento y el saber (Nikolas Rose,1998).

En la mirada cenital, las posibilidades de un conocimiento que hable de imágenes suelen ser desestimadas, porque no son susceptibles al dominio de la evidencia que demanda y que consolida su existencia.

\section{ESCENARIO 2: EN LAS CALLES: LA MIRADA EN EL}

\section{ANDAR:}

En este escenario situamos la mirada al ras del suelo (De Certeau, Ob.Cit.), en la cual se establecen las posibilidades itinerantes que se constituyen en los espacios del andar. Se recupera el espacio de la ciudad recorrida por el caminante como protagonista del conocimiento; por lo tanto, en este actuar no se produce una mirada contemplativa, sino miradas implicadas en las múltiples experiencias como múltiples recorridos pueden generarse. Por ello, en este proceso, no hablamos de una realidad ya constituida sino de posibilidades que se hacen y se deshacen en el devenir: Es la mirada del saber cotidiano y ordinario.

A través de las miradas en el andar se retoman los espacios singulares que pretenden escapar a la disciplina como poder gubernamental, planteando contradicciones entre los dispositivos normativos propios de la mirada cenital en relación al modo individual, corporeizado y experienciante de una reapropiación del espacio que se teje y desteje en el andar. Estas prácticas singulares en el espacio remiten a otra temporalidad diferente a la lógica discursiva y a una espacialidad constituida en las experiencias del cuerpo en el lugar. Por ello su lenguaje preferido es la metáfora.

Las miradas en el andar no reproducen la tensión forzosa entre el sujeto y el objeto y no necesitan de un observador cautivo de los dispositivos de representación de una realidad "válida". El caminante interpreta su propio espacio de conocimiento en itinerarios que se demarcan a partir de la ruptura o la adhesión a ciertas trayectorias, configurando circuitos y nodos de experiencia. En tal sentido, su 
cartografía no es estable, porque implica una concepción distinta del espacio y refiere a conexiones, flujos e itinerarios.

El andar es una práctica que también genera su propia temporalidad, ya que el tiempo se funda como devenir, como proceso y como experiencia. Está libre de la lógica de una narrativa lineal, porque no se ejecuta en contingencias físicas y cronológicas del lenguaje técnico, sino que se explica y adapta a sus propias contingencias.

El escenario de las miradas caminantes se puede representar como lectura estética a través de las imágenes en el circuito urbano que se producen en este devenir; circuito urbano no solo constituido por el trazado de las calles y sus dispositivos de control del flujo peatonal, sino como escenario de la cotidianidad emocional, política, circunstancial, afectiva y efímera, tal y como nos dibuja el arte, corporeizado en la figura del flàneur de Benjamin y otras experiencias estéticas que reivindican el caminar, como dada y la dèrive situacionista. Ellas proponen una re-significación del espacio que contraviene a la mirada cenital.

\section{ESCENARIO 3: LA MIRADA IMPURA. LA CIUDAD ES UNA FORMA Y NOS MOVEMOS EN ELLA.}

Las formas urbanas visten un cuerpo que mira y se desplaza por las calles de la ciudad. Ese cuerpo en experiencia es observador y contempla y también está siendo contemplado porque asume la forma de la ciudad.

La mirada es un lugar a partir del cual la ciudad se constituye, porque nuestra ciudad lleva dentro al observador/intérprete, como también a su contexto y su memoria, tanto como su cuerpo, su sexo y sus deseos formando una unidad. La integración del sujeto dentro de la ciudad, reivindica así su subjetividad.

La metáfora de la visión impura de Aurora Fernández Polanco (2006) presenta este conocer implicado como mirada encarnada, situada, afectiva y participativa.

La mirada impura es la mirada desde las formas. La noción de unidad en las formas que desarrolla George Simmel (1910/2006) se amplía a una concepción mas orientada a la estética en Maffesoli, $(1997,1993)$ y Fernández Christlieb, $(2004 a, 2004 b)$, los cuales enfatizan en el valor de lo afectivo, lo imaginario y lo simbólico de las relaciones cotidianas y sus repercusiones en el grupo. Las formas apuestan por otra epistemología y para pensar en ello, Maffesoli invita a fundar una razón-sensible (1997) que abra las posibilidades de un pensamiento crítico orientado a lo estético y lo imaginario.

\section{Una política de la experiencia estética a través de las formas:}

El arte de nuestros días ha cuestionado la idea de contemplación y se introduce en una estética de la experiencia vinculada a otra política, integrándose e incursionando en los espacios de la ciudad para proponer, cuestionar y crear situaciones que rompan la regularidad y la hegemonía en la vida cotidiana. He aquí tres casos del arte que irrumpen al escenario social. El arte y lo social comienzan a difuminar sus límites:

Juan Loyola y la bandera venezolana: En la Caracas de los 80, Juan Loyola interviene el espacio público replanteando desechos (un coche abandonado o una enorme piedra al borde de la autopista), 
para tornarlos evidentes y extraordinarios al pintarlos de amarillo, azul y rojo, los colores patrios. Desde el punto de vista de la acción política, su trabajo estético irrumpe el escenario público al interpelar el valor cotidiano de los símbolos patrios que hasta el momento permanecían reservados a actuaciones y usos oficiales; pero además, permitió evidenciar que el acceso del "ciudadano común" a tales símbolos patrios, -supuestos patrimonios colectivos-, podían derivar en represión.

Krzysztof Wodiczko: intervención sobre/desde lo monumental: El trabajo de Wodiczko se desarrolla fundamentalmente en Europa y tiene la intención de hurgar y cuestionar la memoria colectiva. Qué mejor recurso que las proyecciones monumentales desde la plaza pública, acudiendo al impacto visual y a los juegos estéticos para generar estos espacios de cuestionamiento, en lugar de acudir a la "solitaria" intimidad del televisor o a la elitesca instalación en el museo. Su juego alude a lo mediático, a lo masivo y a lo monumental

El stencil: los muros hablan: El stencil es una variación del graffitti, que invade las paredes, muros y puertas de las ciudades a través de figuras elaboradas en una plantilla. El arte del stencil, se ha desarrollado en Europa y Estados Unidos y comienza a tener influencia en latinoamérica. Su valor "artístico" no está solo en la imagen plasmada sino en la elaboración de la plantilla que repercute en la calidad de la imagen que se elabora. Su autor es un personaje anónimo e insurrecto, conocido a través de seudónimo y que suponemos en la frontera entre la creación y la transgresión..

El arte del stencil transforma la superficie urbana ante la mirada del espectador anónimo, -cualquier paseante-, que súbitamente encuentra que es interpelado por las paredes.

\section{ESCENA FINAL ¿DESDE DONDE MIRAR? (O QUÉ TIENEN DE ESTÉTICO LAS CIUDADES):}

Los lugares apropiados para generar nuevas formas de decir en la ciudad son los espacios públicos. Para Braidotti (2000) los espacios públicos por ser intermedios y nómades ponen en escena el arte como interpelación.

El nómade es la figuración del tipo de sujeto que ha renunciado a toda idea, nostalgia, deseo de lo establecido, que se mueve a través de los diversos espacios, en una especie de juego entre lo instituido y lo instituyente, subvirtiendo ambos ámbitos. Las performances en el espacio público tienen esta doble característica: la de ser móviles y fugaces, solo contingentes a su espacio y tiempo definido, con lo cual perturban lo que políticamente está instituido como prácticas hegemónicas.

Las incursiones estéticas en los territorios nómadas (Careri, 2005), están al margen del control hegemónico. Intentan recuperar espacios vacíos, líquidos e incluso los "desechos" de la ciudad; lugares no regulados ni por el poder, ni por la sociedad de consumo. Así logran, en particulares actuaciones, hacer frente a la concepción de ciudad mercantil, a la especulación inmobiliaria, a los planes urbanísticos cenitales que pretende devastar los emplazamientos públicos y reformular los centros históricos en función de una ciudad legible, organizada y monumentalizada.

El arte como política en la calle recupera nuevas formas de decir y hacer. Si bien el arte continúa siendo elitista, privilegio de algunos grupos, también es cierto que sus expresiones cada vez tocan más los límites de las acciones colectivas: Son precisamente estos límites los que deben recuperarse e incorporarse como conocimiento de lo social. 
Pero nuestras ciudades no pretenden ser realizaciones estéticas. Sus pretensiones se orientan al confort, a la tecnología y al consumo que a otras políticas de decir y hacer. Tal y como señala Román Alcalá (2005), las ciudades se abren a constituirse en espacios mercantiles, regularizados por las políticas del libre mercado situando al "ciudadano" como potencial consumidor más que como habitante y constructor de estos espacios. Así, las posibilidades de subvertir estos dominios (sin caer en románticas expectativas) están en asumir las ciudades dentro de su contradicción y su paradoja, lo cual conlleva a reivindicar las miradas caminantes y las miradas impuras como contapeso a la mirada cenital.

En tal sentido, es fundamental reivindicar un conocimiento y un hacer fundado en las miradas caminantes que se producen en el devenir y la práctica, posibilitando nuevos espacios y diferentes recorridos producidos por el propio sujeto. Espacios que pueden, si no subvertir, sí generar recorridos alternos a las sociedades panópticas. A través de estas miradas la propuesta está en recuperar los espacios vacíos de la mirada cenital para colmarlos de experiencias particulares pero también colectivas.

La apuesta también se orienta a un nivel más íntimo de implicación, a través de las miradas impuras de las formas que suponen la experiencia estética en el devenir caminante. En ellas, el caminante no es solo observador/actor, sino es la propia ciudad; el caminante que teje y desteje las formas de la ciudad.

\section{Referencias}

Benjamin, Walter (2005): Libro de los Pasajes. Madrid: Akal.

Braidotti, Rosi (2000): Sujetos Nómades. Buenos Aires: Paidós.

Careri, Francisco (2005): Walkscapes. El andar como práctica estética. Barcelona: Gustavo Gili.

Certeau, Michel de (2000). La invención de lo cotidiano 1. Artes de Hacer. México: Universidad Iberoamericana

Fernández Christlieb, Pablo (2004a): El espíritu de la calle: Psicología Política de la Cultura cotidiana. Barcelona: Anthropos.

Fernández Christlieb, Pablo (2004b): La Sociedad Mental. Barcelona: Anthropos.

Fernández Polanco, Aurora (2006): La Visión Impura. Fondos de la Colección Permanente. Museo Nacional Centro de Arte Reina Sofía. Febrero-Septiembre. Madrid.

Foucault, Michel (1984): Space, Knowledge and Power. En Paul Rabinow: The Foucault Reader. (pp. 239-256). New York: Pantheon Books

Foucault, Michel (1976/1980): Preguntas a Michel Foucault sobre la geografía. En M. Foucault. Microfísica del Poder, (pp. 111-124). Madrid: La Piqueta 
Foucault, Michel (1978/2000) La Gubernamentalidad. En M. Foucault: Espacios de Poder. Madrid: La Piqueta \# 6. Reproducida en Tareas. Revista del Centro de Estudios Latinoamericanos, (106), 5-25.

Gadamer, Hans-Georg (2006): Estética y Hermenéutica. Madrid: Neometrópolis.

Maffesoli, Michel (1997) Elogio de la razón sensible: una visión intuitiva del mundo contemporáneo, Barcelona: Paidós.

Maffesoli, Michel (1993) El Conocimiento Ordinario. Compendio de Sociología. México: Fondo de Cultura Económica.

Román Alcalá, Ramón. (2005): De la ciudad nómada a la ciudad ausente. En Román Alcalá (Comp.): La ciudad: ausencia y presencia, (pp.31-48). Córdoba: Plurabelle.

Rose, Nikolas (1999): Powers of freedom. Reframing Political Thought. Cambridge University Press. (buscar capitulo

Simmel, Georg (1910/2006). How is Society Possible? American Journal of Sociology, 16. Extraído el 09 de mayo de 2006, de http://socserv2.socsci.mcmaster.ca/ econ/ugcm/3/l3/simmel/society. 